\title{
Quality assessment of qanat water for drinking and agricultural uses in Tehran
}

\begin{abstract}
Underground water is one of the water resources applied to multiple uses in Tehran City. Hence, today, water resources management and investigation is of high importance and necessity. In the present study, 19 Qanat selected of 65 Qanat of Tehran were identified and sampling was conducted to assess the water quality and quantity. Principal variables such as EC, TDS, pH, TH, DO and others like as $\mathrm{Cl}, \mathrm{K}$, $\mathrm{Na}$, etc., were measured and analyzed. The concentration of anions and cations was measured by titration method. Due to low amount of DO and high amount of some cations and anions available in the studied water, sampled Qanat water was reported unacceptable for drinking use based on the determined standards of Environmental Protection Agency. Although $\mathrm{pH}$ value of the sampling Qanat water was within the standard limit for different uses, but $\mathrm{pH}$ parameter is not to be considered as a determinant factor, because drinking water needs to have several other parameters within permissible limits. According to available standards, all Qanat water is useable for agricultural purposes. Also, quality situation of Tehran Qanat water was reported in Good, Acceptable and medium limits based on Schoeller Diagram.
\end{abstract}

Keywords: underground water, Schoeller Diagram, water pollution, Qanat of Tehran
Volume 2 Issue 2 - 2018

\author{
Naser Ebadati,' Azadeh Haji Hosseini² \\ 'Department of Geology, Islamic Azad University, Iran \\ ${ }^{2}$ Department of Geology, Zaminkav Research Center, Iran
}

Correspondence: Naser Ebadati, Department of Geology, Islamic Azad University, Iran, Email drebadati@iiau.ac.ir

Received: December 20, 2017| Published: April 05, 2018

\section{Introduction}

Water is known as a vital substance available in the Earth planet. Shortage of water resources, as a crucial factor, threaten the life of human; plants and animals in many countries, including Iran, and is considered as a problem for economic and agricultural development. ${ }^{1}$ Description of a Qanat and the technologies used to build such a system has been well documented since early times. The Qanat building process has changed very little since that time. Qanats have been constructed by the hand labor of skilled workers, called Muqannis, who have mastered a great understanding of geology and engineering. A Qanat system, as depicted by Figure 1, consists of the following components..$^{2-5}$ Qanat is of the underground water resources, which is of Ancient Iranian innovations, based on the historical documents. Indeed, Qanat are a kind of drainage and underground water transported to the surface by drainage and is used for irrigation or drinking purposes. ${ }^{6}$ Qanat is a collection of a few bars and one or more kilns (corridor or subterranean canal) with a slope less than the ground slope, which collect the water available in the aquifers of Highlands such as rivers, swamps and ponds with help of gravity force or without any elasticity or electric or thermal energy, only by natural flow and transmit it to low height spots. As seen in most of the Qanats, the slope is around 0.5 percent. The crosssection of the gallery is elliptical with a height of 1.2-2.0 and width of $0.8-1.0 \mathrm{~m}$. In some advanced Qanats, the bed of the tunnel is sealed by a hard material such as mortar. Also, in loose soils, to avoid roof and wall collapse, baked clay rings are employed. On the basis of the distance between the outlet and the mother well, the length of the gallery could vary from few hundred meters to several kilometers. The longest gallery among the Qanats in Iran, i.e. about $120 \mathrm{~km}$, belongs to Zarach Qanat in Yazd province. ${ }^{7}$ Population growth and rising living standards in many countries has led to increasing demand for water to be applied for agricultural, industrial and urban uses. ${ }^{8}$ On the other hand, cities growth, increasing industrial activities and indiscriminate use of chemical fertilizers in agriculture is polluting surface water and underground water which adversely lead to harmful effects on the health of human, animals and plants. ${ }^{9}$ Assessing the quality of underground water in different areas can help to determine the specific user level of underground water resources. Paying attention to the fact that underground water resources of a specific area may have different applications, therefore, quality assessment of those resources will result in the determination of their efficiency. ${ }^{10}$ Iran is located in arid and semi-arid par of earth planet and water supply for different parts of the country is of great importance. ${ }^{11}$ Of the suitable alternatives for water supply for different sectors of the country, especially in arid and semi-arid regions, as well as In the dry areas, increasing groundwater levels will keep the Qanat up. In the capital Tehran, before Karaj river water flows into the city, there exist several Qanat that were flowing in each neighborhood and regions. The most famous Qanat that was reported in Tehran was Haj Mirza Ali Reza Qanat that was drilled at Sarcheshmeh since the time of Fath Ali Shah, and now, after more than 160 years, it flows without interruption. ${ }^{12}$ Some other most principal Qanat of Tehran have been drilled by Haj Mirza Aghasi. Generally, Qanat were classified in three groups in Tehran. First, state Qanat for gardens and palaces, which wholly state-owned assets. Second private Qanat like Farmanfarma and Haj AliReza Qanat, which later were dedicated endowment and third type, such as appropriative Qanat like as Shah Qanat. Mehr Gard is the oldest subterranean Qanat of Tehran, but according to its furnace dealing with Tehran subway lines 1 and 2 in Imam Khomeini Square was badly ruined. ${ }^{13}$ Usually access to underground water is available through different alternatives such as fountains, Qanat, manual wells and semi-deep and deep wells. According to the economic, social, environmental and geographic requirements, each alternative has shown advantages and disadvantages which are interpretable in comparison with each other. Several indices exist in alternatives assessment, but hereby, those ones 
which are related to underground water exploitation alternatives such as spectrum of energy need, water supply level, need to requirements and cares and compatibility with the environment were considered which have been used to compare the above-mentioned alternatives. ${ }^{14}$ The purpose of the study is to identify the active Qanats and its water quality assessment., determination of low water supply of the Qanat, determination of qualitative and quantitative as well as chemical variables of water in active Qanat of Tehran used for different purposes such as drinking and agricultural uses. The appropriate strategy for the exploitation of Qanat water is also provided by the responsible organizations in Tehran, Tehran Municipality and its subsidiaries (the Department of Qanat, Department of parks and green spaces in Tehran, firefighting and safety services organization), agriculture Jihad and industry of Tehran to take advantage of active Qanat of Tehran City. ${ }^{15}$

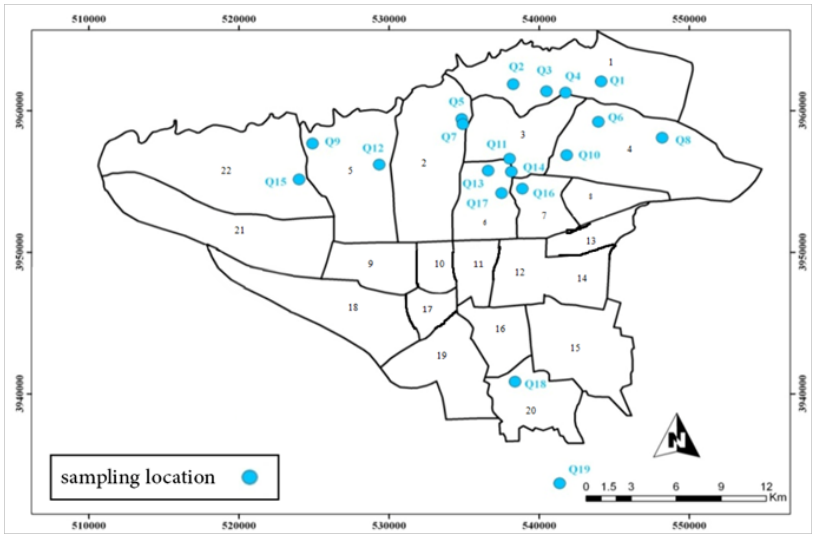

Figure I Map of sampled Qanat location in Tehran City.

\section{Material and method}

In this research, firstly, a preliminary study was carried out through library studies and the collection of reports and maps of the Qanats. Subsequently, with the matching of aerial photos and satellite image of Tehran, the wells of the aqueducts and their route were mapped onto the map. Data transmission was controlled by GIS software in different layers and digitalized points were monitored. At the next stage, at the field survey, sampling of the water withdrawal from the Qanat. And the results of the experiments were compared with the water standards of water consumption. All methods were according to Standard Method of Water and Wastewater. ${ }^{16}$

Table I Variables, analysis method or analysis device

\begin{tabular}{|c|c|c|c|c|}
\hline Parameter & Method or device & Device model & Parameter & Method \\
\hline $\mathrm{pH}$ & $\mathrm{pH}$ meter & $\mathrm{HACH}-\mathrm{I} 7025$ & Chloride & Chloride meter \\
\hline EC & EC meter & $\mathrm{HACH}-17025$ & Calcium hardness & Titration \\
\hline Main cations & atomic absorption of graphite furnace & Mrthrohm883 & Magnesium hardness & Titration \\
\hline Sulfate & spectrophotometer & DR4000 DR6000 & Alkalinity & Titration \\
\hline Nitrate & Spectrophotometer & DR4000 DR6000 & Bicarbonate & Titration \\
\hline Total suspended solids & spectrophotometer & DR4000 DR6000 & Chloride & Titration \\
\hline Turbidity & photometer Turbid- meter & - & Dissolved oxygen & DO meter \\
\hline Total dissolved solids & Gravimetric & - & Potassium and sodium & Flame photo method \\
\hline
\end{tabular}

\section{Studied area}

To select the study area for choosing station and sampling following criteria were investigated: required data availability, complete identification of Qanat route from mother well to symbol well on the earth and inside the furnace, accessibility of water supply by the Qanat for a long period, identification of physical and chemical quality, as well as user situation of Qanat in present condition, determination of the place or places of Qanat water consumption. Based on the above information, the study area was selected in Tehran City between $51^{\circ}, 15^{\prime}, 56^{\prime \prime}$ to $51^{\circ}, 31^{\prime}, 59^{\prime \prime}$ eastern longitude and $35^{\circ}$, $32^{\prime}, 45^{\prime \prime}$ to $35^{\circ}, 48^{\prime}, 00^{\prime \prime}$ northern latitude, positioned in the limitation of 1-2-3-4-5-6-7-2- and 22 regions of Tehran Municipality. ${ }^{17}$

\section{Regional inspections and selection of sampling stations}

To achieve data required for determination of Qanat sampling place and distinguishing active and abandoned Qanat, field visit were carried out by referring to Qanat department of the organization of parks of Tehran and doing the needed coordination. Then, after collecting data using wells location to sampling and qualitative and quantitative assessment, 19 active Qanat of Tehran were identified and selected. Sampling of symbol Qanat place (in the Qanat which has a determined symbol on the earth), and also sampling of mother well in the route of the Qanat (in Qanat which has no symbol on the earth or sampling of the symbol is not accessible) was conducted. Afterwards, samples were sent to laboratory for further investigations in less than two hours. Sampling from water of 19 Qanat of Tehran were done instantly for qualitative assessment.

\section{Sampling method}

Water temperature, EC and $\mathrm{pH}$ were measured in situ using thermometer, $\mathrm{pH}$ meter, Conductivity meter electric devices. ${ }^{18,19}$ Afterwards, to do water sampling of 19 Qanat of Tehran City, random sampling method was used with 1.5liter polyethylene containers (for each point two containers) which has already been prepared and was washed with distilled water, and filled and emptied several times with the water of sampling place. In the Table 1 describes the methods of analysis and the devices used. Prepared sample were considered for measuring anions and cations (Table 2). In this method, after sampling based on 2347 standard, noting the stickers on the sampling containers, number, date, place and time of sampling were determined and then samples were transferred to the laboratory within less than 2 hours. In order to do quantitative assessment, Qanat water supply was measured and samples discharge was calculated and recorded. ${ }^{20,21}$ 
Table 2 Measured Qualitative variables of Qanat (TDS and Do is $\mathrm{mg}^{-1}$ and EC is $\mu \mathrm{mhos} \mathrm{cm}^{-1}$ )

\begin{tabular}{|c|c|c|c|c|c|c|c|c|c|c|c|c|c|}
\hline Qanat No. & EC & TDS & $\mathrm{pH}$ & $\mathrm{Ca}$ & $\mathbf{M g}$ & $\mathbf{N a}$ & $\mathbf{K}$ & CL & $\mathrm{SO}_{4}$ & $\mathrm{NO}_{3}$ & $\mathrm{HCO}_{3}$ & TH & DO \\
\hline QI & 940 & 374 & 7.44 & 125.85 & 17.75 & 48.3 & 0.01 & 95.74 & 112.39 & 43 & 292.84 & 387.29 & 6.22 \\
\hline Q2 & 849 & 392 & 7.69 & 90.18 & 38.3 & 36.11 & 0.01 & 106.38 & 44.1 & 76 & 323.35 & 382.78 & 6.5 \\
\hline Q3 & 1,015 & 414 & 7.2 & 142.68 & 11.91 & 88.55 & 0.64 & 99.28 & 180.11 & 86 & 335.55 & 405.28 & 6.5 \\
\hline Q4 & $|, 08|$ & 442 & 7.2 & 146.29 & 22.63 & 48.3 & 0.14 & 109.98 & 109.98 & 47 & 396.56 & 458.41 & 7.2 \\
\hline Q5 & 815 & 347 & 8.06 & 84.96 & 18.72 & 55.2 & 0.01 & 78.01 & 80.69 & 36 & 262.34 & 289.18 & 6.75 \\
\hline Q6 & $\mathrm{I}, 024$ & 421 & 7.17 & 123.24 & 21.28 & 75.9 & 0.01 & 88.65 & |48.89 & 58 & 341.65 & 395.3 & 6.29 \\
\hline Q7 & 890 & 478 & 7.4 & 95 & 24 & 38 & 2.4 & 43 & 105 & 24 & 323 & 340 & 6.7 \\
\hline Q8 & 907 & 360 & 8.1 & 48.49 & 63.59 & 48.3 & 0.01 & 67.37 & 146.49 & 46 & 292.84 & 382.75 & 6.21 \\
\hline Q9 & 636 & 398 & 7.6 & 65 & 15 & 25 & 2.5 & 28 & 66 & 18 & 250 & 238 & 6.1 \\
\hline QI0 & I,554 & 643 & 7.05 & 119.43 & 40.12 & 96.14 & 0.01 & 166.66 & 21.13 & 56 & 506.38 & 463.31 & 6.9 \\
\hline Q12 & 810 & 445 & 7.5 & 95 & 17 & 37 & 2.3 & 49 & 95 & 23 & 288 & 315 & 5.75 \\
\hline Q13 & 1,310 & 469 & 7.04 & 129.45 & 36.6 & 101.2 & 0.01 & 109.92 & 181.07 & 54 & 427.07 & 473.85 & 5.24 \\
\hline QI4 & 1,103 & 469 & 7.37 & 86.57 & 45.72 & 81.42 & 0.14 & 131.2 & 140.24 & 35 & 305.05 & 404.3 & 6.53 \\
\hline Q15 & 478 & 298 & 7.9 & 44 & 14 & 28 & 2.4 & 20 & 38 & 14 & 195 & 188 & 5.22 \\
\hline Q16 & 1,264 & 537 & 7.67 & 90.98 & 45.72 & 101.2 & I. 14 & 134.74 & 158.49 & 38 & 341.65 & $4|5.3|$ & 6 \\
\hline Q17 & $|, 05|$ & 446 & 7.87 & 86.37 & 31.85 & 89.7 & 1.64 & 95.74 & 150.33 & 14 & 305.05 & 346.73 & 6.37 \\
\hline Q18 & $\mathrm{I}, 032$ & 436 & 7.6 & I I0.22 & 28.45 & 55.2 & 0.01 & 85.1 & 69.16 & 38 & 390.46 & 392.29 & 6.41 \\
\hline Q19 & $\mathrm{I}, 847$ & 794 & 7.56 & $\mid 40.07$ & 48.39 & 129.03 & 9.68 & 205.56 & 157.53 & 134 & 457.57 & 548.88 & 6.81 \\
\hline
\end{tabular}

Physical and chemical parameters measurement method

To determine physical and chemical parameters measurement, variables and analysis method or analysis devices were used as shown in Table 2. Other values were measured for the elements available in the laboratory of Tehran regional water authority and all parameters were determined based on available standards. ${ }^{21,22}$

\section{Properties of tehran city qanat}

\section{Investigation of quantitative properties of qanat}

Based on information of Tehran Regional Water Authority published in 1971, 404 field of Qanat were reported in Tehran City, while in consultant engineer's studies of Mahabqods, 271 fields of Qanat were reported, in $1987 .{ }^{12}$ According to statistics of regional water Authority, in 1997, number of Tehran City Qanat was declared as 459 fields and in some technical reports this was reported as 531 fields, including old and new Qanat. ${ }^{23}$ Length of sampled Qanat was in interval between $200-24000 \mathrm{~m}$. Also, most of them were stretched between 2 to 5 kilometers (Figure 1). Discharge of sampled Qanat in Tehran, according to statistics, were fluctuated between at least less than 10 liters per second to a maximum of 836 liters per second.

\section{Physical and chemical variables of qanat water}

A sampling time cannot be a good criterion to evaluate the quality of water resources, but the analysis of these results can show an overview of the quality of water resources. In general water quality parameters are classified in three categories of physical, chemical and biological parameters. Of them, physical and chemical parameters were investigated in this study. Accordingly, the results of the sampling carried out in accordance with the standards and models, were reviewed and analyzed. Moreover, in order to be more accurate analysis of qualitative condition of identified Qanat of Tehran City, water of 19 Qanat was tested and results were analyzed, which are presented in Table 2.

\section{Result and discussion \\ Chloride changes}

Sampled Qanat were different in terms of having variant spectrum of chloride amount. Farmanfarma and Deh kheir Qanat with $21 \mathrm{mgl}^{-1}$ and $206 \mathrm{mgl}^{-1}$ had the lowest and highest levels of chloride, respectively. Chloride amount of samples are lower than optimal standard levels for drinking and agricultural use and suitable for both those mentioned uses (Figure 2). In the figures the black line represents the optimal level for drinking water and the blue line represents the limit.

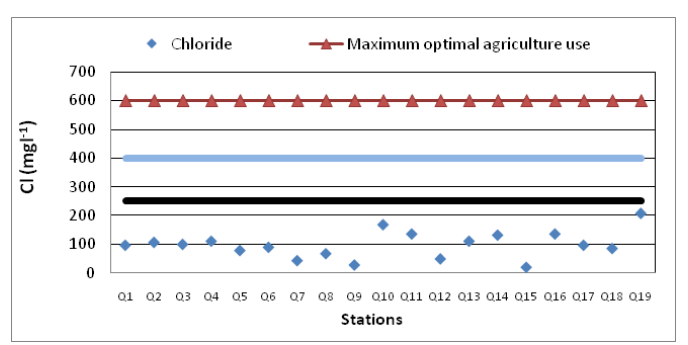

Figure 2 Chloride changes in sampled Qanat water based on drinking and agricultural uses standard (black line represents the optimum level for drinking water and the blue line represents limit). 


\section{Hardness changes}

Based on standard, total optimal hardness and total acceptable hardness were determined as $200 \mathrm{mgl}^{-1}$ for drinking use (according to $\mathrm{CaCO}_{3}$ ) and $500 \mathrm{mgl}^{-1}$ for and agricultural (according to $\mathrm{CaCO}_{3}$ ), respectively. ${ }^{20,24}$ Results represented that. In terms of hardness, level, all sampled Qanat of studied area are placed in hard and quiet hard classification, but based on standard, except Farmanfarma Qanat which is lower than optimal level, and others are lower than acceptable limit. Figure 3 shows the water quality map based on the total hardness.

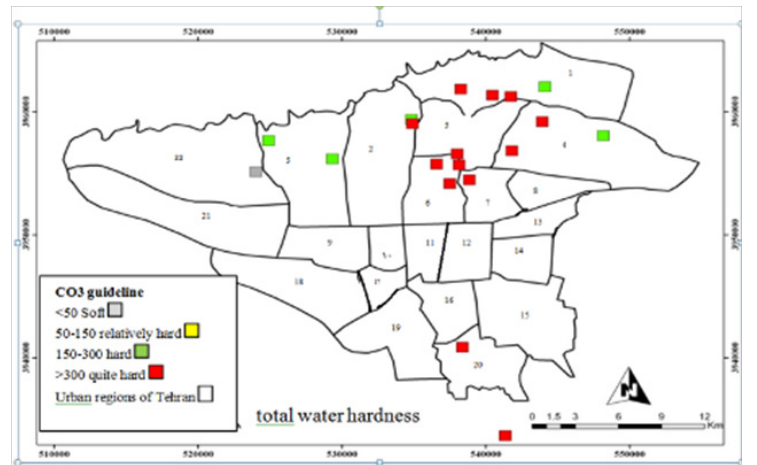

Figure 3 Map of total water hardness changes in sampled Qanat of Tehran City $\left(\mathrm{mgl}^{-1}\right)$.

\section{Sulfate changes}

According to Standard, optimal and acceptable sulfate level was determined as $250 \mathrm{mgl}^{-1}$ and $400 \mathrm{mgl}^{-1}$ for drinking use, respectively. Results show that sulfate spectrum was so variant in the studied Qanat shows in Figure 4. Mehran Zartoshti and Yousefabad Qanat with $21 \mathrm{mgl}^{-1}$ and $181 \mathrm{mgl}^{-1}$ had the lowest and highest amount of sulfate, respectively. Also, sulfate amount in the sampled Qanat was lower than optimal standard level for drinking use. ${ }^{16}$

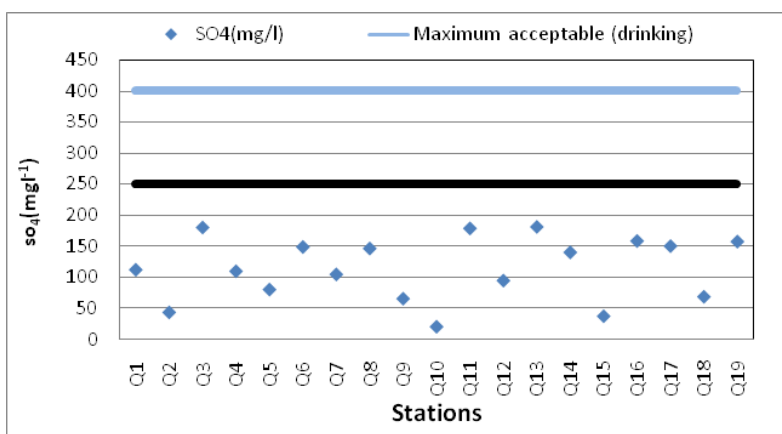

Figure 4 Sulfate changes in sampled Qanat of Teharn City based on drinking use standard (blue line represents the optimal level for drinking water).

\section{Schoeller classification}

To investigate quality of drinking water using results of sampled Qanat, Schoeller classification method was used. ${ }^{25}$ Figure 5 demonstrates Schoeller diagram related to sampled Qanat in Tehran City. Study of the mentioned Figure 5 showed that, regarding Total Dissolved Solid (TDS), 79\% and 21\% was reported as good and acceptable and regarding Total Hardness $(\mathrm{TH}), 10.55,84 \%$ and $5.5 \%$ were reported as good, acceptable and medium, respectively.
Moreover, 58\%, 16\% and 26\% were reported as good, acceptable and medium level for $\mathrm{pH}$ amount. For anions, in terms of having sodium amount, $98.5 \%, 10.5 \%$ were in good and acceptable range, respectively. $95 \%$ and $5 \%$ were the limits which were reported as good and acceptable level for Chloride amount. For sulfate, $58 \%$ and $42 \%$ were shown to be in good and acceptable range, respectively. Study showed that parameters are ranged in good and acceptable limit and a percent of $\mathrm{TH}$ and acidity $(\mathrm{pH})$ was in medium range.

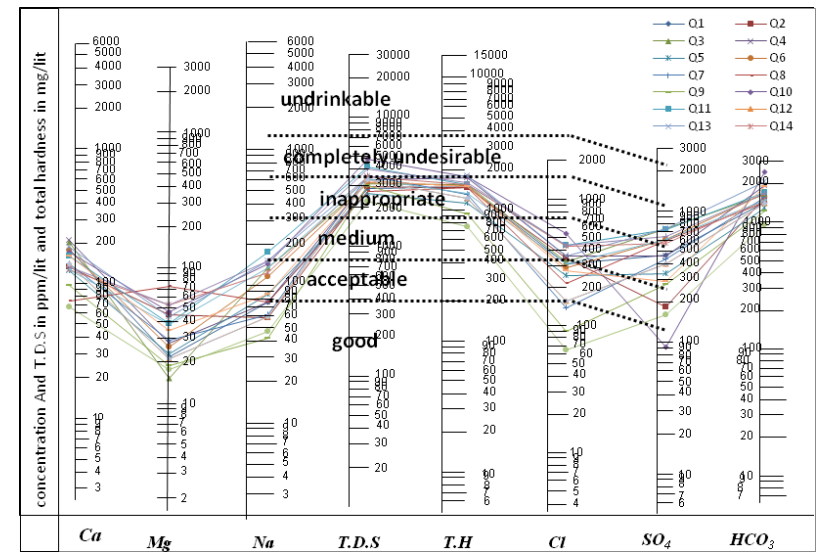

Figure 5 Scholler Diagram of sampled Qanat of Tehran City.

\section{Salinity changes (agricultural use)}

Generally, Total Dissolved Salt in irrigation water is measured by determining electric conductivity (EC) as $\mu$ mhos $\mathrm{cm}^{-1}$ or by determining real salt ppm. Results shows that EC of sampled Qanat of Tehran is lower than standards limit and Figure 6 presented EC amounts with agriculture water standard. ${ }^{16}$

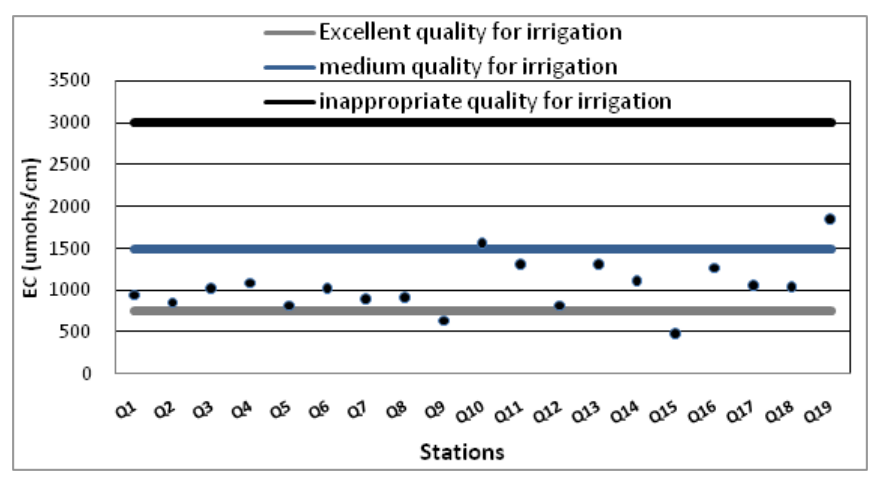

Figure 6 EC changes of sampled Qanat of Tehran City with agricultural use standards.

\section{Based on wilcox index (for agricultural use)}

According to Wilcox diagram for all sampled Qanat of the studied area, in terms of SAR were not suitable for agricultural use, but regarding salinity level, Can and Farmanfarma Qanat were slightly salty and the others were reported salty. Moreover, based on classifications of water quality of studied Qanat in Tehran City using Wilcox diagram, these two above mentioned Qanat, Can and Farmanfarma were considered amongst good waters and the others were in medium limit in Figure 7. 


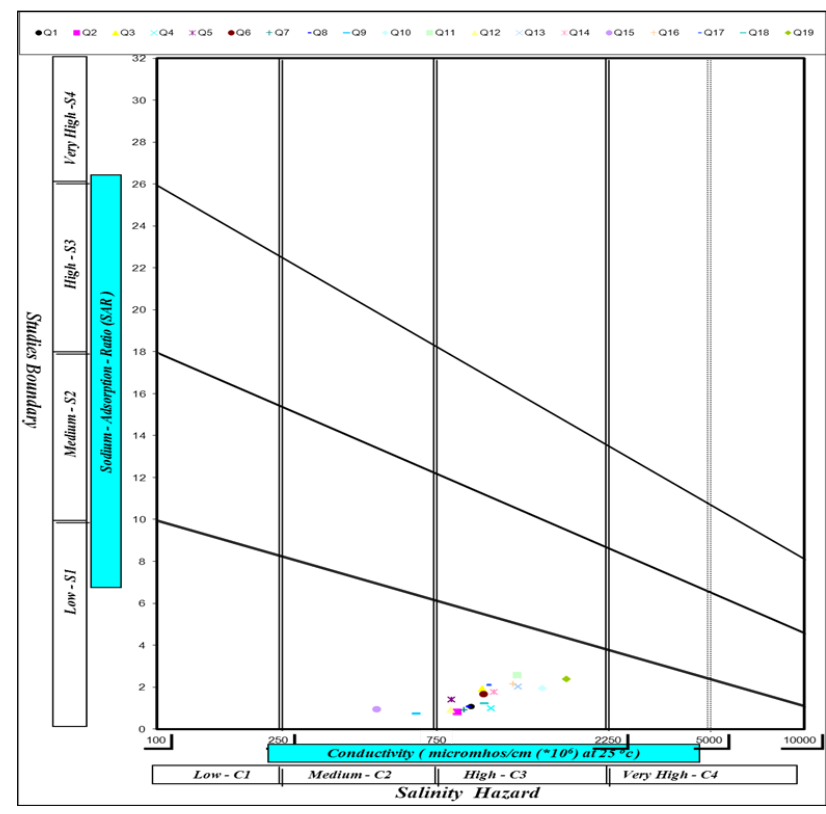

Figure 7 Qualitative condition of sampled Qanat of Tehran city based on

Wilcox salinity index.

\section{Conclusion}

According to the studies conducted, water of sampled Qanat was considered inappropriate for drinking use due to low DO amount, high amount of cations and anions available in water based on determined standards of Environmental Protection Agency. Although $\mathrm{pH}$ of sampled water was in the range of mentioned standard for different uses, but $\mathrm{pH}$ is not a determinative factor solely, and use of drinking water require having multiple standard parameters. Also, moving from west to east and north to south, anions and cations amount increases and is considered suitable for agricultural use based on available standards:

-In terms of cations and anions, Farmanfarma Qanat was lower than optimal limit and the others were lower than acceptable limit.

i. According to drinking use standards, Firouzeh (Golab), Qeytariyeh, Mobarak Abad, Mehran Zartoshti, Yousef Abad and Deh kheir Qanat were higher than acceptable limit, in terms of nitrate amount.

ii. In terms of Chloride and sulfate amounts, compared to drinking use standards, all sampled Qanat were lower than optimal standard limit.

iii. On the basis of Schoeller diagram, studies showed that all parameters were in good and acceptable limits and a percent of TH and $\mathrm{pH}$ were ranged in medium limit.

iv. Based on agriculture use standards, of the studied Qanat, Qolqoleh, Can, Abas Abad 1, Baq-e-Feiz, Farmanfarma and Russia were lower than acceptable limit in terms of nitrate amount.

v. EC and chloride amount were lower than acceptable limit for agricultural use.

vi. In terms of Sodium attraction ratio (SAR), sodium attraction percent and RSC index of all sampled Qanat was profited a suitable condition qualitatively. vii. According to classification of water quality in sampled Qanat of Tehran City, based on Wilcox method, maximum of the studied Qanat were in medium range.

\section{Acknowledgments}

The authors would like to express their acknowledgment of the organization of parks of Tehran municipality for cooperation in achieving the information, as well as laboratory of Tehran regional water Authority for collaboration in conducting the water quality tests.

\section{Conflict of interest}

The authors declare no conflict of interest.

\section{References}

1. Mehdipour A, Bani SM, Qaem MM. Analysis of the influence of sand dams to increase the discharge of Qanat. Tehran: International Conference of Qanat; 2005. p. 315.

2. Abdin S. Qanats a Unique Groundwater management tool in arid regions: the case of bam region in Iran. ISGWAS. 2016;1-9.

3. Boustani F. Sustainable Water Utilization in Arid Region of Iran by Qanats. Proc World Acad Sci Eng Technol. 2008;33:213-216.

4. Farzadmehr J, Nazari Samani AA. A review of Iran's Qanats (type, current situation, advantageous and disadvantageous) as a traditional method for water supply in Arid and semi arid regions. In: The 2nd International Conference on Water, Ecosystems, and Sustainable Development in Arid and Semi-Arid Zones; 2009 May 6-11, Tehran, Yazd, Iran; 2009.

5. Qanats. Water history. 2015.

6. Goudarzi M, Islamian S. Investigation of released flood Systems and fed artificial ponds depends on Baq-e-Sorkh Qanat "Shahreza". Iran: International Conference of Qanat; 2005. p. 518-523.

7. Molle F, Mamanpoush A, Miranzadeh M. Robbing Yadullah's water to irrigate Saeid's garden: hydrology and water rights in a village of central Iran. Research Reports: Vol. 80. International Water Management Institute, Colombo, Sri Lanka. 2004. p. 1-52.

8. Faithful J, Finlayson W. Water quality assessment for sustainable agriculture in the Wet Tropics-A community assisted approach. Marine pollution Bulletin. 2005;51(1-4):99-112.

9. Patwardhan A, Sahasrabuddhe, Mahabaleshwarkar, et al. Changing status of urban water bodies and associated health concern in Pune India. Proceedings of the Third International Conference on Environment and Health. 2003;1-7.

10. Sarani N, Soltani J, Sarani S, et al. Comparison of Artificial Neural Network and Multivariate Linear Regression Model to Predict Sodium adsorption ratio (SAR),(Case Study: Sistan River, Iran). Ecology and Environmental Sciences. 2012;1-5.

11. Aganabati A. Geological of Iran. published Geological survey of Iran; 2004.

12. Toossab Consulting Engineers Company. Study of Qantas water quality of in Tehran. Toossab Consulting Engineers Company; 2015. p. 215.

13. Maleki A, Khorsandi A. Qanat in Iran The Case Study Of Tehran Qanats. Tehran: Processing Enterprises and Urban Planning; 2005. p. 234-257.

14. Wulff HE. The Qanats of Iran. Scientific American; 1968. p. 94-105.

15. Ebadati N, Behzad N. Investigating the Pollution of Ground waters in Rey-Varamin (Iran). IAHR International Groundwater Symposium: Flow and Transport in Heterogeneous Subsurface Formations: Theory, Modeling \& Applications 2008: proceeding; 2008 June 18-20; Istanbul, Turkey; 2008, p. 96. 
16. APHA. Standard Methods for the Examination of Water and Wastewater American public Health Association; 2005. p. 541.

17. Amini B. Geological map of Tehran, Geological survey of Iran. series of scale $1: 250000 ; 1993$.

18. Ebadati N, Hoshmandzade M. Water Quality evaluation of Dez River in the Dezful hydrometric station. Journal of Eco hydrology. 2014;1(2):6981 .

19. Dahaghani M, Azam K, Mohamadi A. An Investigation on PhysicoChemical and Microbiological Quality of Public Swimming Pools in Tehran City. Journal of research environmental health. 2015;(1):29-35.

20. World health organization: WHO. Guidelines for drink water WHO. Wuliy, Volume 102 and 3 WHO, GENEVA. (Swimming pools and similar environment). Geneva: World Health Organization; 2004. p. 316-112.
21. ISIRI. Chemical Specifications of Drinking Water. Institute of Standards and Industrial Research of Iran, Tehran; 2009.

22. Esmaeili SA. Pollutants, hygiene and standards in the environment. Tarbiat Modarres University; 2012. p. 124.

23. Tabatabaei SH. Removal of trace elements in municipal wastewater by using Iranian Natural Zeolites. Tehran university: Irrigation and claymation Dept; 2001. p. 135

24. World health organization: WHO. Study protocol for the world health organization project to develop a quality of life assessment instrument (WHOQOL). Quality of life research. 1993;2(2):153-159.

25. Schoeller H. Qualitative Evaluation of Groundwater Resources. In: Methods and Techniques of Groundwater Investigation and Development. Water Resources. 1965;33:44-52. 